\title{
Protective Effect of Thiaton, an Antispasmodic Drug, Against Indomethacin-Induced Intestinal Damage in Rats
}

\author{
Tomonori Kunikata, Tohru Miyazawa, Kenji Kanatsu, Shinichi Kato and Koji Takeuchi* \\ Department of Pharmacology and Experimental Therapeutics, Kyoto Pharmaceutical University, \\ Misasagi, Yamashina, Kyoto 607-8414, Japan
}

Received June 6, 2001 Accepted October 9, 2001

\begin{abstract}
The effect of thiaton [3-(di-2-thienylmethylene)-5-methyl-trans-quinolizidinium bromide], an antispasmodic drug, on indomethacin-induced intestinal damage was examined in rats. The animals were given indomethacin, s.c., and the intestinal mucosa was examined $24 \mathrm{~h}$ later. Thiaton or atropine was given s.c. twice, $30 \mathrm{~min}$ before and $8 \mathrm{~h}$ following indomethacin. Indomethacin caused intestinal damage, accompanied with increase in enterobacterial translocation as well as inducible nitric oxide synthase (iNOS) and myeloperoxidase (MPO) activities, and these changes were significantly prevented by supplementation with 16,16-dimethyl prostaglandin $\mathrm{E}_{2}\left(\mathrm{dmPGE}_{2}\right)$. Treatment of the animals with thiaton dose-dependently prevented the intestinal damage, together with the suppression of MPO and iNOS activities, and these effects were similarly observed by atropine. The increase of bacterial translocation was also significantly prevented by both thiaton and atropine, similar to $\mathrm{dmPGE}_{2}$. Indomethacin enhanced intestinal motility, and this effect was inhibited by either thiaton, atropine or $\mathrm{dmPGE}_{2}$. The intestinal mucus and fluid secretions were decreased by indomethacin but enhanced by $\mathrm{dmPGE}_{2}$. Both thiaton and atropine slightly decreased these secretions under basal conditions but significantly reversed the decrease in the secretions caused by indomethacin. These results suggest that thiaton protects the small intestine against indomethacin-induced damage and inflammatory changes, and this effect is related with prevention of enterobacterial translocation, the process being associated with inhibition of intestinal hypermotility caused by indomethacin, probably due to anti-muscarinic action.
\end{abstract}

Keywords: Thiaton, Antispasmodic drug, Indomethacin-induced intestinal lesion, Intestinal motility, Enterobacterial translocation

Administration of nonsteroidal anti-inflammatory drugs (NSAIDs) such as indomethacin to human or experimental animals causes damage in the small intestine and the stomach as an adverse reaction $(1-3)$. Several factors have been postulated as the pathogenic element of indomethacin-induced intestinal lesions, including bacterial translocation, neutrophils and nitric oxide (NO) overproduction, in addition to prostaglandin (PG) deficiency $(4-8)$. Especially, the presence of enterobacteria is a key pathogenic element in this model, because antibiotics such as metronidazole and ampicillin are known to prevent not only the occurrence of intestinal lesions but the accompanying inflammatory changes as well, including increases of myeloperoxidase (MPO) and inducible NO synthase (iNOS) activities $(7-11)$. We recently found that indo-

*Corresponding author. FAX: +81-75-595-4774

E-mail: takeuchi@mb.kyoto-phu.ac.jp methacin at the ulcerogenic dose enhanced intestinal motility, which precedes of the occurrence of intestinal damage (12).

Thiaton [3-(di-2-thienylmethylene)-5-methyl-trans-quinolizidinium bromide], the anti-spasmodic drug, is shown to produce amelioration of gastrointestinal motor disorders as well as antiulcer effects and is used for treatment of patients with irritable bowel syndrome in Japan $(13-15)$. This drug is a potent nonselective muscarinic antagonist and acts on the gastrointestinal (GI) tract, causing spasmolytic effects, although the antimuscarinic action in eye and salivary gland is much less potent than that in the GI tract $(13,16)$. Because intestinal hypermotility may play a role in the pathogenic mechanism of indomethacininduced small intestinal lesions (12), it might be possible that thiaton prevents these lesions by suppressing the intestinal hypermotility. However, there is no study examining the effect of thiaton on NSAID-induced small intestinal 
lesions.

Given the above background, we evaluated the effect of thiaton on indomethacin-induced small intestinal lesions in rats, in comparison with atropine. We also examined the anti-spasmodic effect of thiaton on indomethacin-induced intestinal hypermotility and correlated this effect with the protective action against the small intestinal lesions.

\section{MATERIALS AND METHODS}

\section{Animals}

Male Sprague Dawley rats (200 - 230 g; Nippon Charles River, Shizuoka) were used. The experiments were performed using 5-6 non-fasting rats per group under unanesthetized conditions, unless otherwise specified. All experimental procedures employed in the present study were approved by the Experimental Animal Research Committee of the Kyoto Pharmaceutical University.

\section{General procedures}

The animals were administered indomethacin s.c. in a dose of $10 \mathrm{mg} / \mathrm{kg}$, and the small intestinal mucosa was examined $24 \mathrm{~h}$ later for damage, bacterial translocation as well as other biochemical parameters such as MPO and iNOS activities (10). Using this lesion model, the effects of thiaton, atropine and 16,16-dimethyl prostaglandin $E_{2}$ $\left(\mathrm{dmPGE}_{2}\right)$ on the intestinal ulcerogenic response to indomethacin were examined. In a separate study, the effects of these agents on intestinal mucus secretion and enteropooling (fluid secretion) as well as intestinal hypermotility caused by indomethacin were examined.

\section{Induction of small intestinal lesions}

The animals were administered indomethacin $(10 \mathrm{mg} / \mathrm{kg})$ s.c., killed $24 \mathrm{~h}$ later under deep ether anesthesia, and both the jejunum and ileum were removed and treated with $2 \%$ formalin for fixation of the tissues $(10,11)$. Then, they were opened along the anti-mesenteric attachment and examined for lesions under a dissecting microscope with square grids $(\times 10)$. The area $\left(\mathrm{mm}^{2}\right)$ of macroscopically visible lesions was measured, summed per small intestine, and used as a lesion score. The person measuring the lesions did not know the treatments given to the animals. Thiaton $(1-30 \mathrm{mg} / \mathrm{kg})$ or atropine $(3 \mathrm{mg} / \mathrm{kg})$ was given s.c. twice, $30 \mathrm{~min}$ before and $8 \mathrm{~h}$ after administration of indomethacin, while $\mathrm{dmPGE}_{2}(10 \mu \mathrm{g} / \mathrm{kg})$ was given i.v. twice $10 \mathrm{~min}$ before and $6 \mathrm{~h}$ after indomethacin.

\section{Measurement of enterobacterial translocation}

Twenty-four hours after administration of indomethacin, the animals were killed under deep ether anesthesia, and the small intestines were removed. After rinsing the intestine with sterile saline, the mucosa was scraped with glass slides, weighed, and homogenized in $1 \mathrm{ml}$ of sterile phosphate buffer saline (PBS) per $100 \mathrm{mg}$ wet tissue. The aliquot of the homogenate was placed on blood agar and GAM agar (Nissui, Osaka). Blood agar plates were incubated at $37^{\circ} \mathrm{C}$ for $24 \mathrm{~h}$ under aerobic conditions, while GAM agar plates were incubated for $48 \mathrm{~h}$ under standard anaerobic conditions (BBL Gas Pack Pouch Anaerobic System; Becton Deckinson, MD, USA). Plates containing 10-200 colony-forming units (CFU) were examined for the number of enterobacteria that had invaded in the small intestine, and the data were expressed as $\log \mathrm{CFU} / \mathrm{g}$ tissue. Thiaton $(10 \mathrm{mg} / \mathrm{kg})$ or atropine $(3 \mathrm{mg} / \mathrm{kg})$ was given s.c. twice, $30 \mathrm{~min}$ before and $8 \mathrm{~h}$ after administration of indomethacin, while $\mathrm{dmPGE}_{2}(10 \mu \mathrm{g} / \mathrm{kg})$ was given i.v. twice $10 \mathrm{~min}$ before and $6 \mathrm{~h}$ after indomethacin.

\section{Determination of MPO activity}

MPO activity was measured according to the modified method of Bradley et al. (17). In brief, $24 \mathrm{~h}$ after indomethacin treatment, the animals were killed under deep ether anesthesia, and the small intestines were removed. After rinsing the intestine with cold saline, the mucosa was scraped with glass slides, weighed and homogenized in $50 \mathrm{mM}$ phosphate buffer containing $0.5 \%$ hexadecyltrimethyl-ammonium bromide (HTAB, pH 6.0; Sigma Chemicals, St. Louis, MO, USA). The homogenized samples were subjected to freeze and thaw three times and centrifuged at $2,000 \mathrm{rpm}$ for $10 \mathrm{~min}$ at $4^{\circ} \mathrm{C}$. MPO activity in the supernatant was determined by adding $100 \mu \mathrm{l}$ of the supernatant to $1.9 \mathrm{ml}$ of $10 \mathrm{mM}$ PBS (pH 6.0) and $1 \mathrm{ml}$ of $1.5 \mathrm{M} \mathrm{o}$-dianisidine hydrochloride (Sigma) containing $0.0005 \% \mathrm{w} / \mathrm{v}$ hydrogen peroxide. The changes in absorbance at $450 \mathrm{~nm}$ of each sample were recorded on a Hitachi spectrophotometer (U-2000; Hitachi, Ibaraki). Sample protein content was estimated by the spectrophotometric assay (Pierce Protein Assay Kit; Pierce, Rockford, IL, USA), and the MPO activity was obtained from the slope of the reaction curve, based on the following equation: Specific activity $\mu \mathrm{mol} \mathrm{H}_{2} \mathrm{O}_{2} \cdot \mathrm{min}^{-1} \cdot \mathrm{mg}$ protein ${ }^{-1}=\left(\mathrm{OD} \cdot \mathrm{min}^{-1}\right)$ $/\left(\mathrm{OD} \cdot \mu \mathrm{mol} \mathrm{H}_{2} \mathrm{O}_{2}{ }^{-1} \cdot \mathrm{mg}\right.$ protein $)$. Thiaton $(10 \mathrm{mg} / \mathrm{kg})$ or atropine $(3 \mathrm{mg} / \mathrm{kg})$ was given s.c. twice, $30 \mathrm{~min}$ before and $8 \mathrm{~h}$ after administration of indomethacin, while $\mathrm{dmPGE}_{2}(10 \mu \mathrm{g} / \mathrm{kg})$ was given i.v. twice $10 \mathrm{~min}$ before and $6 \mathrm{~h}$ after indomethacin.

\section{Measurement of NOS activity}

Intestinal mucosal NOS activity was measured by determining the conversion of radiolabeled L-arginine to citrulline, according to the method described by Brown et al. (18). Twenty-four hours after administration of indomethacin, the animals were killed by deep ether anesthesia, and the small intestines were removed. After rinsing the intestine with cold saline, the mucosa was scraped, and homo- 
genized in ice-cold buffer ( $50 \mathrm{mM}$ Tri-HCl, $32 \mathrm{mM}$ sucrose, $1 \mathrm{mM}$ dithiothreitol, $10 \mu \mathrm{g} / \mathrm{ml}$ leupeptin and $2 \mu \mathrm{g} / \mathrm{ml}$ aprotinin), adjusted to $\mathrm{pH} 7.4$ with $\mathrm{NaOH}$, followed by centrifugation for $20 \mathrm{~min}$ at $10,000 \mathrm{rpm}$ at $4^{\circ} \mathrm{C}$. The supernatant was incubated for $60 \mathrm{~min}$ at $37^{\circ} \mathrm{C}$ in reaction buffer comprising $50 \mathrm{mM}$ Tris- $\mathrm{HCl}$ buffer, $1.25 \mathrm{mM} \mathrm{CaCl}$, $12.5 \mathrm{mM}$ valine, $1 \mathrm{mM}$ dithiothreitol, $10 \mu \mathrm{M}$ L-arginine, $100 \mu \mathrm{M}$ NADPH, $10 \mu \mathrm{M}$ FAD, $10 \mu \mathrm{M}$ FMN and $0.5 \mu \mathrm{Ci}$ $/ \mathrm{ml}\left[{ }^{3} \mathrm{H}\right]$-L-arginine. The reaction was arrested by removal of the substrate L-arginine with addition of an aliquot of $50 \%$ suspension of Dowex (AG $50 \mathrm{~W}-8, \mathrm{Na}^{+}$form) in water, and each sample was centrifuged at 3,000 rpm for $5 \mathrm{~min}$. After allowing the resin to settle, the supernatant was removed for estimation of the ratio-labeled products by scintillation counting. The activity of constitutive NOS (cNOS) was determined from the difference between in the presence and absence of $1 \mathrm{mM}$ EGTA; the activity of iNOS was determined in the absence of $1 \mathrm{mM}$ EGTA. Sample protein content was estimated by the spectrophotometric assay as described above, and the NOS activity was expressed as $\mathrm{pmol} \cdot \mathrm{min}^{-1} \cdot \mathrm{mg}$ protein ${ }^{-1}$. Thiaton $(10 \mathrm{mg}$ $/ \mathrm{kg})$ or atropine $(3 \mathrm{mg} / \mathrm{kg})$ was given s.c. twice, $30 \mathrm{~min}$ before and $8 \mathrm{~h}$ after administration of indomethacin, while $\mathrm{dmPGE}_{2}(10 \mu \mathrm{g} / \mathrm{kg})$ was given i.v. twice $10 \mathrm{~min}$ before and $6 \mathrm{~h}$ after indomethacin.

\section{Determination of intestinal motility}

Intestinal motility was determined using a miniature balloon according to a previous paper (19). In brief, the rat was anesthetized with urethane $(1.25 \mathrm{~g} / \mathrm{kg}$, i.p.), and the trachea was cannulated to facilitate respiration. Following a midline incision to expose the small intestine, a thin, saline-filled balloon, made from silicone rubber and attached to a polyethylene catheter, was introduced into the jejunum via a small incision and tied in place avoiding large blood vessels. The volume in the balloon was adjusted to give an initial resting pressure of $5 \mathrm{mmHg}$, which was not sufficient to cause active distension of the intestinal wall, and after allowing the preparation to rest for $30 \mathrm{~min}$, intestinal motility was monitored on a recorder (U-228; Tokai-irika, Tokyo) as intraluminal pressure changes, through a pressure transducer and polygraph device (Nihon Kodan, Ibaraki). Indomethacin $(10 \mathrm{mg} / \mathrm{kg})$ was given s.c. after basal motor activity had well stabilized, while thiaton $\left(3-30 \mathrm{mg} / \mathrm{kg}\right.$, s.c.), atropine $\left(3 \mathrm{mg} / \mathrm{kg}\right.$, s.c.) or $\mathrm{dmPGE}_{2}$ $(10 \mu \mathrm{g} / \mathrm{kg}$, i.v.) was given $30 \mathrm{~min}$ or $10 \mathrm{~min}$, respectively, before administration of indomethacin. In some cases, these agents were given $2 \mathrm{~h}$ after indomethacin treatment. Quantitation of intestinal motility was done by measuring the area of motility changes in a recording sheet using NIH image 1.61 (NIH, Bethesda, MD, USA), and the data were expressed as the motility index (arbitrary unit).

\section{Determination of intestinal mucus contents}

The animals, which had been fasted for $18 \mathrm{~h}$, were administered s.c. with indomethacin $(10 \mathrm{mg} / \mathrm{kg})$, thiaton $(10 \mathrm{mg}$ $/ \mathrm{kg})$, atropine $(3 \mathrm{mg} / \mathrm{kg})$ or i.v. with $\mathrm{dmPGE}_{2}(10 \mu \mathrm{g} / \mathrm{kg})$. Three hours later, they were killed under deep ether anesthesia, and the small intestines were removed $(30 \mathrm{~cm})$ and opened along the anti-mesenteric attachment. In some animals, thiaton, atropine or $\mathrm{dmPGE}_{2}$ was given s.c. $30 \mathrm{~min}$ or $10 \mathrm{~min}$ before administration of indomethacin. The mucus contents including soluble mucus and adherent mucus gel were measured according to the method previously described by Azumi et al. (20). Briefly, the intestinal mucosa was immersed in $20 \mathrm{ml}$ of PBS containing $2 \%(\mathrm{w} / \mathrm{v}) \mathrm{N}$ acetylcysteine, and gently stirred with a magnetic stirrer for $5 \mathrm{~min}$ at room temperature. Then, the mucosa was gently rinsed with $10 \mathrm{ml}$ of PBS twice, and the solution recovered from these rinsing steps was pooled as the adherent mucus sample. After lyphophilization, the powdered samples were dissolved in $4 \mathrm{ml}$ of $50 \mathrm{mM}$ Tris- $\mathrm{HCl}$ (pH 7.2) containing $2 \%$ Triton X-100, homogenized with a Polytron tissue homogenizer (IKA, Yokohama) and centrifuged at $10,000 \mathrm{rpm}$ at $4^{\circ} \mathrm{C}$ for $30 \mathrm{~min}$. An aliquot of the supernatant was applied onto the Sepharose 2B (Pharmacia Biotech, Uppsala, Sweden) $/ 50 \mathrm{~cm}$ column and eluted with the $50 \mathrm{mM}$ Tris- $\mathrm{HCl}(\mathrm{pH} 7.2)$ containing $2 \%$ Triton X-100. The void volume fraction was collected, and hexose contents were measured as mucin. Hexose content in this fraction was measured by the phenol-sulfuric acid method, using galactose as the standard, and the results were expressed as $\mu \mathrm{g}$ hexose $/ \mathrm{cm}$ tissue.

\section{Determination of enteropooling (fluid secretion)}

Enteropooling assay was performed as a test examining the effect on water secretion, according to the method described by Robert et al. (21). In this study, the animals were deprived of food for $18 \mathrm{~h}$ but allowed free access to tap water until $1 \mathrm{~h}$ before the experiment. They were administered s.c. with indomethacin $(10 \mathrm{mg} / \mathrm{kg})$, thiatone $(10 \mathrm{mg} / \mathrm{kg})$, atropine $(3 \mathrm{mg} / \mathrm{kg})$ or i.v. with $\mathrm{dmPGE}_{2}$ $(10 \mu \mathrm{g} / \mathrm{kg})$. Three hours later, the animals were killed by deep ether anesthesia, the abdomen was opened, and both the pylorus and the end of the ileum were clamped immediately. Then, the fluid accumulated in the lumen of the small intestine was collected in the graduated tube, centrifuged for $10 \mathrm{~min}$ at $3000 \mathrm{rpm}$, and the volume was measured to the nearest $0.01 \mathrm{ml}$. In some animals, thiaton (s.c.), atropine (s.c.) or $\mathrm{dmPGE}_{2}$ (i.v.) was given 30 or $10 \mathrm{~min}$, respectively, before administration of indomethacin.

\section{Preparation of drugs}

Drugs used were urethane (Tokyo Kasei, Tokyo), thiaton (Hokuriku Seiyaku Co., Ltd., Fukui), indomethacin (Sigma), 
atropine (Nacalai Tesque, Kyoto) and 16,16-dimethyl prostaglandin $\mathrm{E}_{2}$ (dmPGE 2 ; Funakoshi, Tokyo). Indomethacin was suspended in saline with a drop of Tween 80 (Wako, Osaka), while thiaton or atropine was suspended in carboxymethylcellulose (CMC, Nacalai Tesque) solution. $\mathrm{dmPGE}_{2}$ was first dissolved in absolute ethanol and then diluted with saline to the desired concentration. Other drugs were dissolved in saline. All drugs were prepared immediately before use and administered s.c. and p.o. in a volume of $0.5 \mathrm{ml} / 100 \mathrm{~g}$ body weight or i.v. in a volume of $0.1 \mathrm{ml}$ $/ 100 \mathrm{~g}$ body weight.

\section{Statistics}

Data are presented as the means \pm S.E.M. from 5 to 6 rats per group. Statistical analyses were performed by the two-tailed Student's $t$-test or Dunnett's multiple comparison test, and values of $P<0.05$ were regarded as significant.

\section{RESULTS}

Effects of thiaton, atropine and $d m P G E_{2}$ on small intestinal damage caused by indomethacin

Single s.c. administration of indomethacin $(10 \mathrm{mg} / \mathrm{kg})$ provoked severe hemorrhagic lesions in the small intestine, mostly the jejunum and ileum, the lesion score being $258.2 \pm 21.6 \mathrm{~mm}^{2}$ (Fig. 1). The development of intestinal lesions in response to indomethacin was dose-dependently prevented by thiaton $(1-30 \mathrm{mg} / \mathrm{kg})$ given twice $30 \mathrm{~min}$ before and $8 \mathrm{~h}$ after indomethacin, the degree of inhibition at 10 and $30 \mathrm{mg} / \mathrm{kg}$ being $95.5 \%$ and $98.1 \%$, respectively. Likewise, the development of small intestinal lesions in response to indomethacin was also significantly inhibited

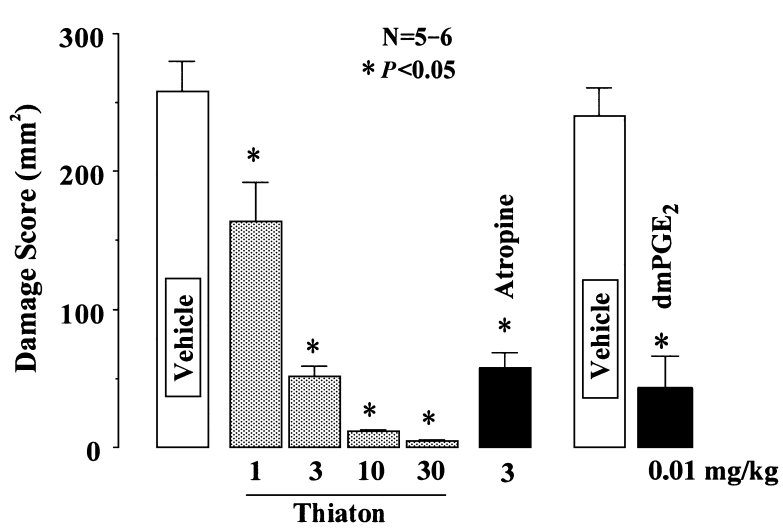

Fig. 1. Effects of thiaton, atropine and $\mathrm{dmPGE}_{2}$ on indomethacininduced small intestinal lesions in rats. The animals were given indomethacin $(10 \mathrm{mg} / \mathrm{kg})$ and killed $24 \mathrm{~h}$ later. Thiaton and atropine were given s.c. twice $30 \mathrm{~min}$ before and $8 \mathrm{~h}$ after indomethacin, while $\mathrm{dmPGE}_{2}$ was given i.v. $10 \mathrm{~min}$ before and $6 \mathrm{~h}$ after indomethacin. Data are presented as the means \pm S.E.M. from $5-6$ rats. * Significant difference from the vehicle at $P<0.05$. by atropine at $3 \mathrm{mg} / \mathrm{kg}$, s.c., the degree of inhibition being $77.7 \%$. Certainly, when the animals were pretreated with $\mathrm{dmPGE}_{2}(10 \mu \mathrm{g} / \mathrm{kg}$, i.v. $)$ twice, $10 \mathrm{~min}$ before and $6 \mathrm{~h}$ after administration of indomethacin, this agent significantly reduced the severity of intestinal lesions, and the degree of inhibition was $82.6 \%$.

Effects of thiaton, atropine and $d m P G E_{2}$ on changes in intestinal MPO and iNOS activities caused by indomethacin

The MPO activity was $0.005 \pm 0.001 \mu \mathrm{mol} \mathrm{H}_{2} \mathrm{O}_{2} / \mathrm{mg}$ protein in the normal intestinal mucosa and markedly elevated in response to indomethacin, reaching $0.344 \pm$ $0.032 \mu \mathrm{mol} \mathrm{H}_{2} \mathrm{O}_{2} / \mathrm{mg}$ protein $24 \mathrm{~h}$ later (Fig. 2). The increased MPO activity was significantly suppressed by s.c. treatment of the animals with either thiaton $(10 \mathrm{mg} / \mathrm{kg})$ or atropine $(3 \mathrm{mg} / \mathrm{kg})$, the inhibition being $94.2 \%$ or $91.3 \%$, respectively. Likewise, dmPGE ${ }_{2}$ significantly prevented the increase of MPO activity following indomethacin, and the values at $24 \mathrm{~h}$ later were $0.04 \pm 0.02 \mu \mathrm{mol} \mathrm{H}_{2} \mathrm{O}_{2} \cdot \mathrm{min}^{-1}$ $\cdot$ mg protein ${ }^{-1}$.

On the other hand, the iNOS activity in the normal intestinal mucosa was $0.40 \pm 0.34 \mathrm{pmol} \cdot \mathrm{min}^{-1} \cdot \mathrm{mg}$ protein ${ }^{-1}$ (Fig. 3). Subcutaneous administration of indomethacin markedly increased iNOS activity in the intestinal mucosa when determined $24 \mathrm{~h}$ later, reaching about 8 times greater than basal levels, the values being $2.84 \pm 0.17 \mathrm{pmol} \cdot \mathrm{min}^{-1}$ $\cdot \mathrm{mg}$ protein $^{-1}$. The increased iNOS activity following indomethacin was significantly reduced by pretreatment of the animals with thiaton $(10 \mathrm{mg} / \mathrm{kg}$, s.c.), atropine $(10 \mathrm{mg} / \mathrm{kg}$, s.c. $)$ or $\mathrm{dmPGE}_{2}(10 \mu \mathrm{g} / \mathrm{kg}$, i.v. $)$ at the doses that significantly prevented the occurrence of intestinal

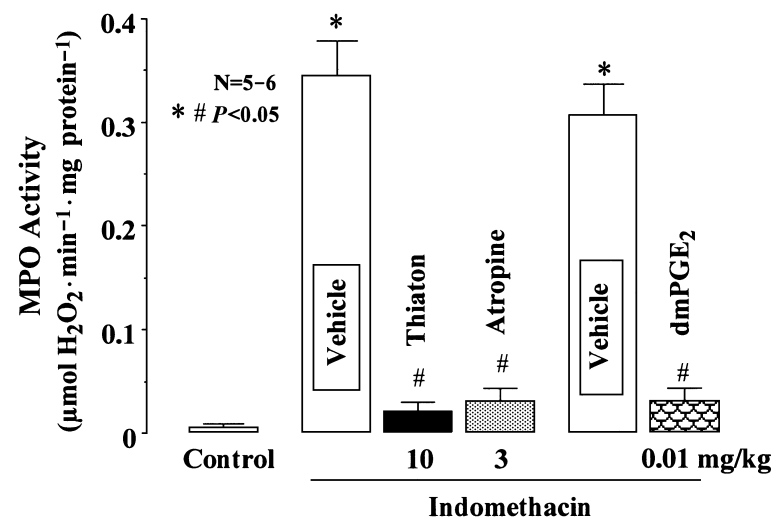

Fig. 2. Effects of thiaton, atropine and $\mathrm{dmPGE}_{2}$ on changes in $\mathrm{MPO}$ activity in the small intestinal mucosa in response to indomethacin in rats. The animals were given indomethacin $(10 \mathrm{mg} / \mathrm{kg})$ and killed $24 \mathrm{~h}$ later. Thiaton and atropine were given s.c. twice $30 \mathrm{~min}$ before and $8 \mathrm{~h}$ after indomethacin, while $\mathrm{dmPGE}_{2}$ was given i.v. $10 \mathrm{~min}$ before and $6 \mathrm{~h}$ after indomethacin. Data are presented as the means \pm S.E.M. from 5-6 rats. Significant difference at $P<0.05$ : *from the control, ${ }^{\#}$ from the vehicle. 


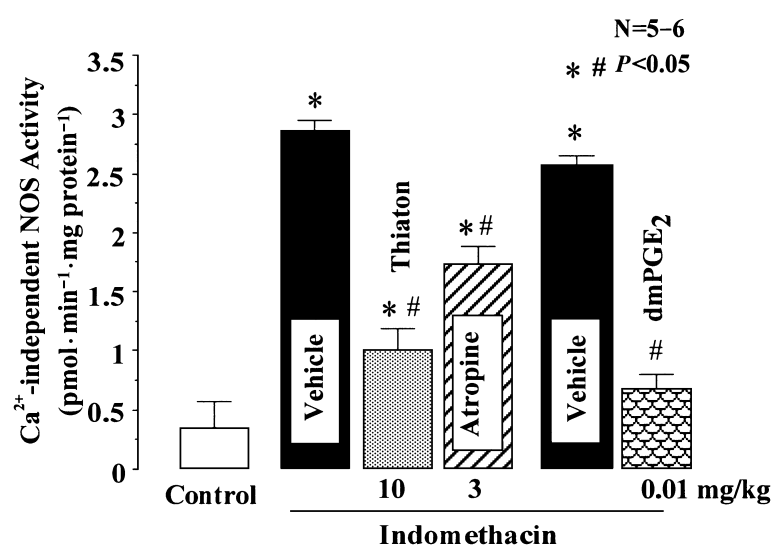

Fig. 3. Effects of thiaton, atropine and $\mathrm{dmPGE}_{2}$ on changes in iNOS activity in the small intestinal mucosa in response to indomethacin in rats. The animals were given indomethacin $(10 \mathrm{mg}$ $/ \mathrm{kg}$ ) and killed $24 \mathrm{~h}$ later. Thiaton and atropine were given s.c. twice $30 \mathrm{~min}$ before and $8 \mathrm{~h}$ after indomethacin, while $\mathrm{dmPGE}_{2}$ was given i.v. $10 \mathrm{~min}$ before and $6 \mathrm{~h}$ after indomethacin. Data are presented as the means \pm S.E.M. from $5-6$ rats. Significant difference at $P<0.05$ : *from the control, ${ }^{*}$ from the vehicle.

ulcerations, the inhibition being $65.2 \%, 39.7 \%$ or $75.3 \%$, respectively. Neither of these agents had any effect on cNOS activity in the intestinal mucosa (not shown).

Effects of thiaton, atropine and $d m P G E_{2}$ on changes in enterobacterial translocation caused by indomethacin

The aerobic and anaerobic enterobacterial numbers in the normal intestinal mucosa were $6.53 \pm 0.19 \log \mathrm{CFU} / \mathrm{g}$

Table 1. Effects of thiaton, atropine and $\mathrm{dmPGE}_{2}$ on enterobacterial translocation caused by indomethacin

\begin{tabular}{|c|c|c|c|c|}
\hline \multirow{2}{*}{ Treatment } & \multirow{2}{*}{$\begin{array}{c}\text { Dose } \\
(\mathrm{mg} / \mathrm{kg})\end{array}$} & \multirow{2}{*}{$\begin{array}{l}\text { No. of } \\
\text { rats }\end{array}$} & \multicolumn{2}{|c|}{ Numbers of bacteria $(\log \mathrm{CFU} / \mathrm{g})$} \\
\hline & & & aerobic & anaerobic \\
\hline Control & - & 5 & $6.53 \pm 0.19$ & $6.51 \pm 0.22$ \\
\hline Indomethacin & 10 & & & \\
\hline + Vehicle & - & 5 & $10.51 \pm 0.26^{\mathrm{a}}$ & $10.51 \pm 0.33^{\mathrm{a}}$ \\
\hline + Thiaton & 10 & 6 & $7.33 \pm 0.20^{\mathrm{b}}$ & $7.99 \pm 0.12^{\mathrm{b}}$ \\
\hline+ Atropine & 3 & 6 & $7.80 \pm 0.23^{\mathrm{b}}$ & $7.97 \pm 0.32^{\mathrm{b}}$ \\
\hline Indomethacin & 10 & & & \\
\hline + Vehicle & - & 5 & $10.69 \pm 0.11^{\mathrm{a}}$ & $10.72 \pm 0.07^{\mathrm{a}}$ \\
\hline$+\mathrm{dmPGE}_{2}$ & 0.01 & 6 & $8.06 \pm 0.38^{\mathrm{b}}$ & $8.06 \pm 0.32^{\mathrm{b}}$ \\
\hline
\end{tabular}

The animals were given indomethacin $(10 \mathrm{mg} / \mathrm{kg})$, and the number of bacteria in the small intestinal mucosa was counted $24 \mathrm{~h}$ later. Thiaton and atropine were given s.c. twice $30 \mathrm{~min}$ before and $8 \mathrm{~h}$ after indomethacin, while $\mathrm{dmPGE}_{2}$ was given i.v. $10 \mathrm{~min}$ before and $6 \mathrm{~h}$ after indomethacin. Data are presented as the means \pm S.E.M. from 5-6 rats. Significant difference at $P<0.05$ : ${ }^{a}$ from the control, ${ }^{\mathrm{b}}$ from the vehicle. tissue and $6.51 \pm 0.22 \log \mathrm{CFU} / \mathrm{g}$ tissue, respectively (Table 1). Following subcutaneous administration of indomethacin $(10 \mathrm{mg} / \mathrm{kg})$, the enterobacterial numbers in both aerobic and anaerobic bacteria were markedly increased to approximately 1,000-fold greater than the controls, the values being $10.51 \pm 0.26 \log \mathrm{CFU} / \mathrm{g}$ tissue and $10.51 \pm$ $0.33 \log \mathrm{CFU} / \mathrm{g}$ tissue, respectively. Prior administration of thiaton $(10 \mathrm{mg} / \mathrm{kg}$, s.c.) significantly prevented the increase of enterobacterial numbers in the mucosa following indomethacin. The enterobacterial translocation in indomethacin-treated animals was also significantly prevented by prior administration of atropine $(3 \mathrm{mg} / \mathrm{kg}$, s.c.) or $\mathrm{dmPGE}_{2}(10 \mu \mathrm{g} / \mathrm{kg}$, i.v. $)$. Either of these agents was similarly effective in reducing the number in both aerobic and anaerobic bacterium.

Effects of thiaton, atropine and $d m P G E_{2}$ on intestinal motility changes following administration of indomethacin

Subcutaneous administration of indomethacin $(10 \mathrm{mg} / \mathrm{kg})$ caused a marked enhancement of intestinal motility, with regard to both the amplitude and frequency of contraction. The enhanced intestinal motility caused by indomethacin was suppressed by prior s.c. administration of thiaton (3$30 \mathrm{mg} / \mathrm{kg}$ ) in a dose-dependent manner (Fig. 4A). When this agent $(30 \mathrm{mg} / \mathrm{kg})$ was given $2 \mathrm{~h}$ after administration of indomethacin, the clear amplitude of contraction almost totally disappeared, resulting in fluctuations at the baseline which were difficult to characterize as contraction spikes (Fig. 5). Likewise, the intestinal hypermotility seen following administration of indomethacin was markedly inhibited in the presence of atropine $(3 \mathrm{mg} / \mathrm{kg}$, s.c. $)$ as well as $\mathrm{dmPGE}_{2}(10 \mu \mathrm{g} / \mathrm{kg}$, i.v. $)$, similar to the case of thiaton (Fig. 4B). Either of these agents alone decreased basal intestinal motility (not shown).

\section{Effects of thiaton, atropine and $d m P G E_{2}$ on intestinal mucus secretion and enteropooling}

Mucus secretion: Total amount of mucus in the small intestine under basal conditions was $8.40 \pm 0.76 \mu$ g galactose $/ \mathrm{cm}$ tissue. The mucus contents significantly decreased in response to indomethacin $(10 \mathrm{mg} / \mathrm{kg})$, reaching the values of $4.90 \pm 0.41 \mu \mathrm{g}$ galactose $/ \mathrm{cm}$ tissue $3 \mathrm{~h}$ later, approximately $41.7 \%$ of basal values (Fig. 6). Although both thiaton $(10 \mathrm{mg} / \mathrm{kg}$, s.c.) and atropine $(3 \mathrm{mg} / \mathrm{kg}$, s.c.) did not have any effect on the basal mucus secretion, either of these agents significantly restored the decrease of mucus secretion in response to indomethacin. On the other hand, $\mathrm{dmPGE}_{2}(10 \mu \mathrm{g} / \mathrm{kg}$, i.v. $)$ significantly increased the mucus secretion, in the absence or presence of indomethacin. Following administration of $\mathrm{dmPGE}_{2}$ alone, the mucus secretion in normal rats increased to about 1.7 times the control values, reaching $15.2 \pm 1.3 \mu \mathrm{g}$ galactose $/ \mathrm{cm}$ tissue.

Enteropooling: The control rats accumulated a signifi- 

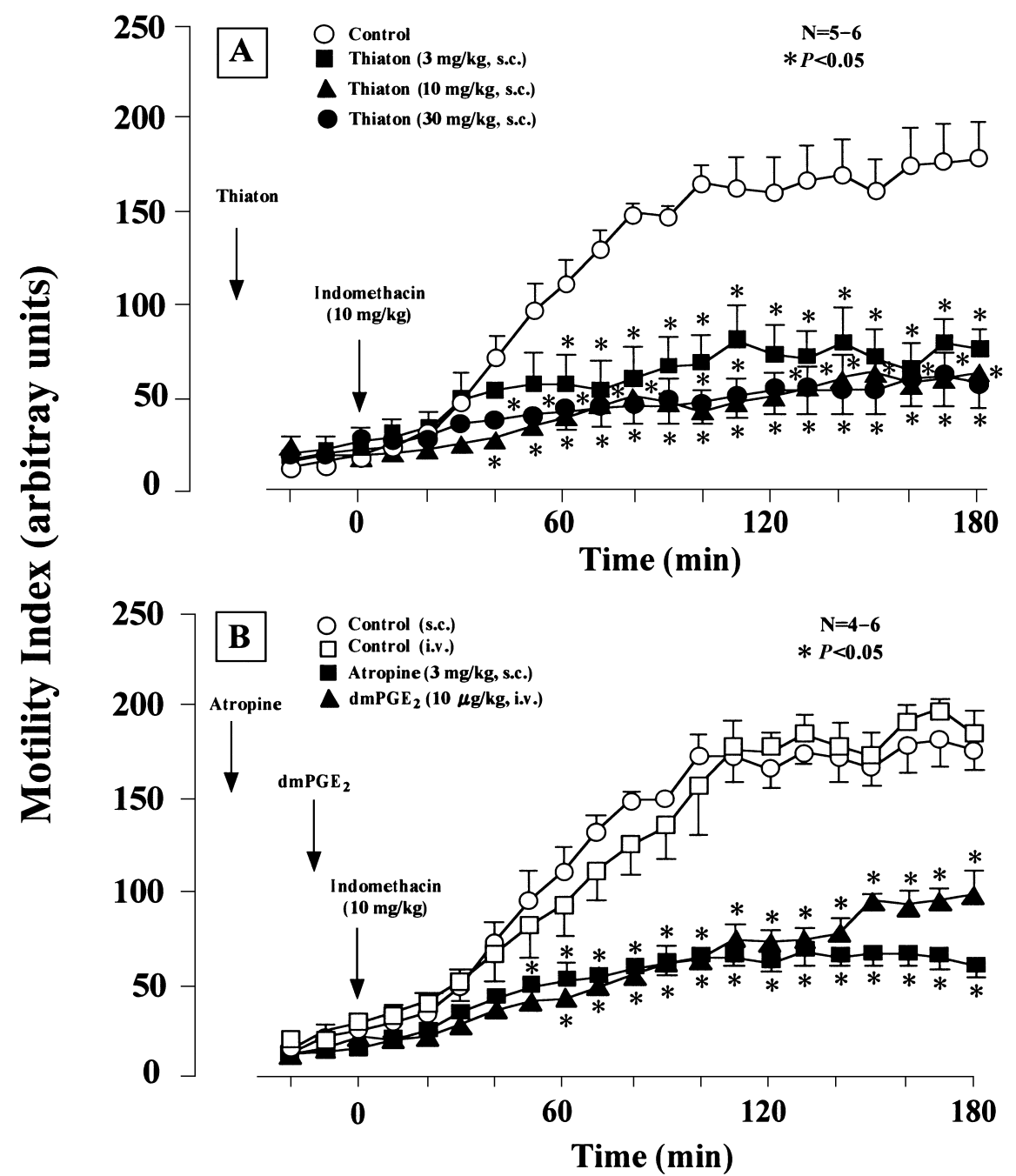

Fig. 4. Effects of thiaton (A), atropine (B) and $\mathrm{dmPGE}_{2}(\mathrm{~B})$ on the enhanced small intestinal motility induced by indomethacin in rats. Indomethacin $(10 \mathrm{mg} / \mathrm{kg})$ was given s.c. $1 \mathrm{~h}$ after the basal motility had stabilized. Thiaton $(3-30 \mathrm{mg} / \mathrm{kg}$, s.c. $)$, atropine (3 mg/kg, s.c.) or $\mathrm{dmPGE}_{2}(10 \mu \mathrm{g} / \mathrm{kg}$, i.v.) was given $30 \mathrm{~min}$ or $10 \mathrm{~min}$, respectively, before administration of indomethacin. Quantitation of intestinal motility was done using NIH image 1.61. Data are expressed as the motility index (arbitrary unit) and presented as the mean \pm S.E.M. from $4-6$ rats. ${ }^{*}$ Significant differnce from the respective control at $P<0.05$.

cant amount of fluid in the small intestine, the volume being $0.18 \pm 0.02 \mathrm{ml}$ for $3 \mathrm{~h}$ (Fig. 7). Subcutaneous administration of indomethacin $(10 \mathrm{mg} / \mathrm{kg})$ significantly decreased the volume of fluid accumulated in the small intestine, the reduction being $60.1 \%$. Both thiaton $(10 \mathrm{mg} / \mathrm{kg}$, s.c.) and atropine $(3 \mathrm{mg} / \mathrm{kg}$, s.c.) caused a slight but significant decrease in the intestinal fluid secretion, yet these agents tended to revert the reduced fluid secretion following indomethacin treatment. In contrast, $\mathrm{dmPGE}_{2}(10 \mu \mathrm{g}$ $/ \mathrm{kg}$, i.v.) significantly increased the intestinal fluid secretion to about 2 times greater than the control values, in the absence or presence of indomethacin.

\section{DISCUSSION}

Thiaton, the anti-spasmodic drug, has been shown to exhibit the antiulcer effect as well as the cytoprotective action in the stomach and also ameliorate the gastrointestinal motor disorders $(13-16)$. However, no study has been reported concerning the protective effect of this drug on the intestinal ulcerogenic response induced by NSAIDs. The present study showed for the first time that thiaton prevented the development of small intestinal lesions following administration of indomethacin. In addition, we also demonstrated the importance of intestinal hypermotility in the pathogenesis of indomethacin-induced small intestinal lesions and that prevention by thiaton of the intestinal hypermotility may account for the protective effect of this 

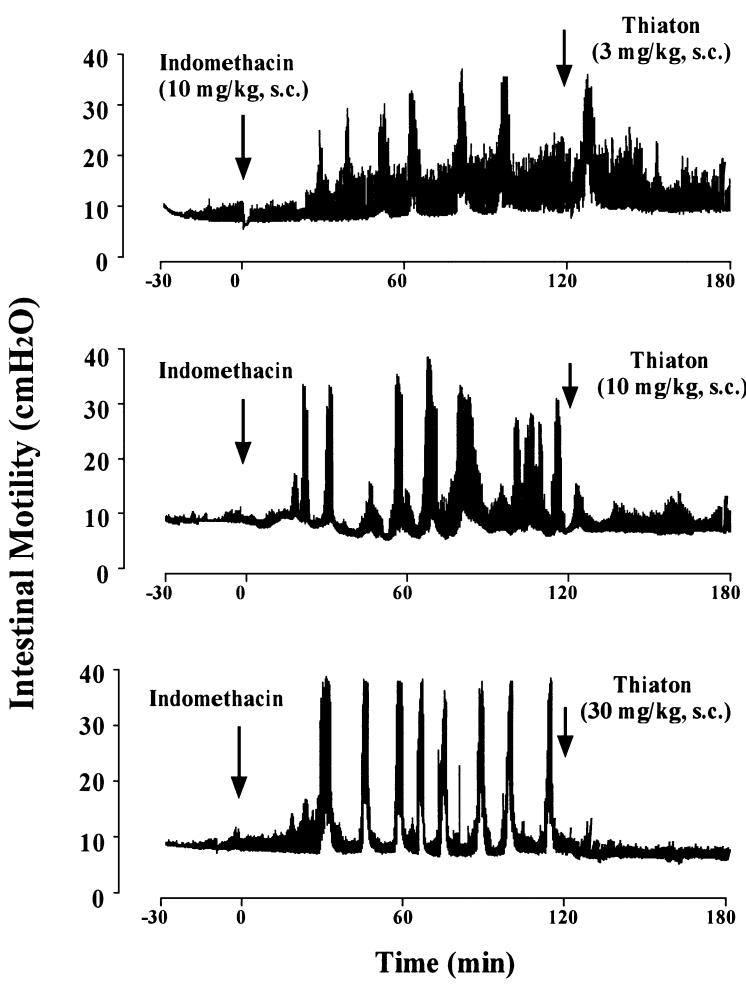

Fig. 5. Representative recordings showing the inhibitory effect of thiaton on indomethacin-induced intestinal hypermotility in rats. Indomethacin $(10 \mathrm{mg} / \mathrm{kg})$ was given s.c. $1 \mathrm{~h}$ after the basal motility had stabilized. Thiaton $(3-30 \mathrm{mg} / \mathrm{kg})$ was given s.c. $2 \mathrm{~h}$ after indomethacin. Note that thiaton potently inhibited the intestinal hypermotility caused by indomethacin.

drug against these lesions.

First, we confirmed that indomethacin-induced intestinal lesions was markedly prevented by supplementation with $\mathrm{dmPGE}_{2}$, together with other various changes in the mucosa such as increases in MPO and iNOS activities $(10,11)$. Several factors have been postulated as the patho- genic element of indomethacin-induced intestinal ulceration, including PG depletion, enterobacteria, neutrophil and NO (4-9). Among them, the bacterial translocation is considered to play a major pathogenic role in the development of intestinal lesions following indomethacin, because these lesions were completely prevented by pretreatment of the animals with antibiotics such as ampicillin and metronidazole $(5,7,9-11)$. Indeed, it was reported that bacterial endotoxin enhanced the intestinal permeability through increased expression of iNOS and overproduction of NO in the mucosa $(8,9)$. In the present study, we found that thiaton prevented the bacterial translocation and the development of these lesions following administration of indomethacin. Furthermore, this drug significantly prevented not only the occurrence of intestinal lesions after indomethacin but also the accompanying changes in various inflammatory parameters, such as the increase of iNOS and MPO activities. Interesting, these effects of thiaton were mimicked by prior administration of atropine, the anti-muscarinic drug. These results support the pivotal role for enterobacterial translocation in the pathogenesis of intestinal ulceration (9) and suggest that the protective effect of thiaton against intestinal lesions may be closely associated with inhibition of this process, responsible for excessive NO production through induction of iNOS $(8$, $10)$. Thus, it is possible that thiaton somehow hampers the process of bacterial translocation in the intestinal mucosa following indomethacin. Yet, just how indomethacin caused an increase of the bacterial translocation in the small intestine or how thiaton interferes the enterobacterial translocation remains unknown. Since the latter effect was similarly observed by the anti-muscarinic drug atropine and since thiaton shows high affinity at the muscarinic receptors of the gastrointestinal smooth muscle $(13,14$, 16 ), it is assumed that the latter effect may be brought about by their anti-muscarinic action.

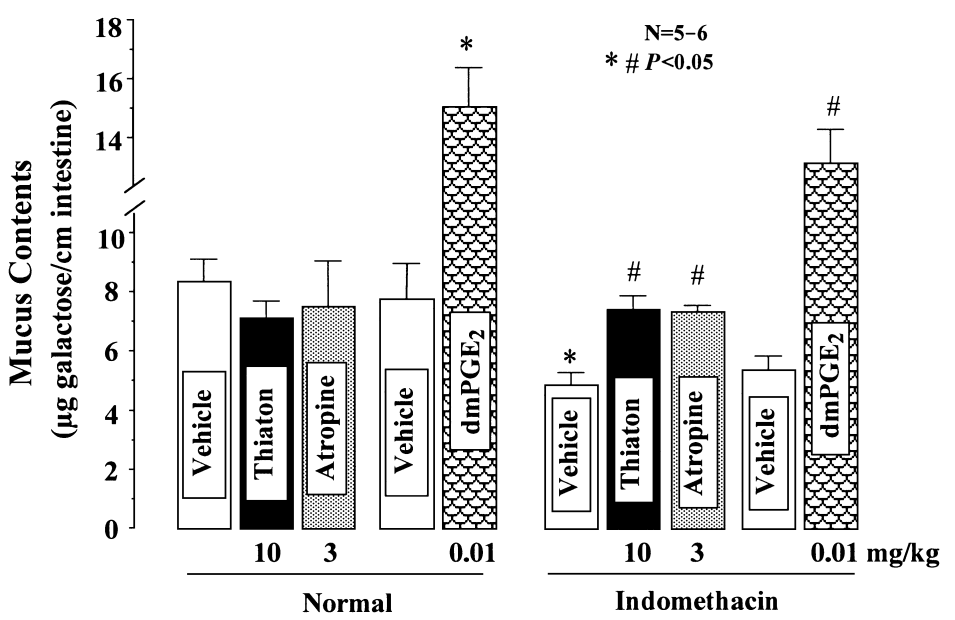

Fig. 6. Effects of thiaton, atropine and $\mathrm{dmPGE}_{2}$ on small intestinal mucus contents in rats, in the absence or presence of indomethacin. The animals were given indomethacin $(10 \mathrm{mg} / \mathrm{kg})$, and the mucus contents in the small intestine was measured $3 \mathrm{~h}$ later. Thiaton and atropine were given s.c. $30 \mathrm{~min}$ before indomethacin, while $\mathrm{dmPGE}_{2}$ was given i.v. $30 \mathrm{~min}$ before indomethacin. Data are presented as the means \pm S.E.M. from 5-6 rats. Significant difference at $P<0.05$ : * from the vehicle in the normal group, "from the vehicle in the indomethacin group. 

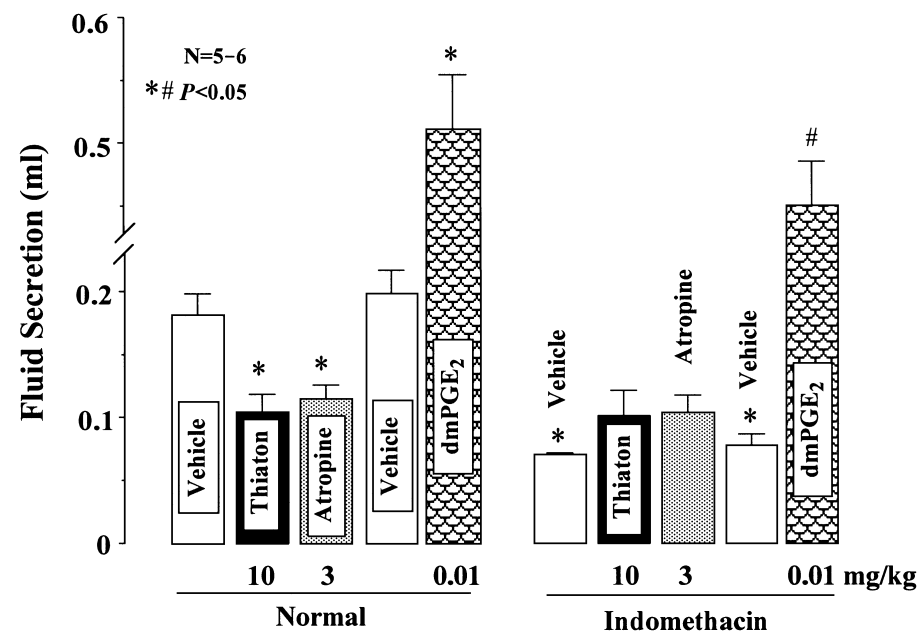

Fig. 7. Effects of thiaton, atropine and $\mathrm{dmPGE}_{2}$ on small intestinal fluid secretion (enteropooling) in rats, in the absence or presence of indomethacin. The animals were given indomethacin $(10 \mathrm{mg} / \mathrm{kg})$, and the amount of fluid in the small intestine was measured $3 \mathrm{~h}$ later. Thiaton and atropine were given s.c. $30 \mathrm{~min}$ before indomethacin, while $\mathrm{dmPGE}_{2}$ was given i.v. $30 \mathrm{~min}$ before indomethacin. Data are presented as the means \pm S.E.M. from $5-6$ rats. Significant difference at $P<0.05$ : *from the vehicle in the normal group, "from the vehicle in the indomethacin group.
We have recently found that indomethacin at the ulcerogenic dose enhanced intestinal motility, preceding the occurrence of intestinal damage (12). Because the spasmodic nature of the intestinal motility results in disruption of unstirred mucus layer over the epithelium, leading to increase of the mucosal susceptibility to pathogens and irritants, it is assumed that the enhanced intestinal contraction is involved in the pathogenic mechanism of indomethacin-induced small intestinal lesions. In the present study, we confirmed that indomethacin markedly enhanced intestinal motility, resulting in an increase of both the amplitude and frequency of the contraction, and this motility change occurred much earlier than the onset of bacterial translocation that was observed $2-3 \mathrm{~h}$ after indomethacin treatment (10). Thiaton dose-dependently inhibited the intestinal hypermotility following administration of indomethacin, and this action was similarly observed by atropine as well as $\mathrm{dmPGE}_{2}$. Both thiaton and atropine may inhibit the intestinal hypermotility response to indomethacin through anti-muscarinic action $(13,14,16)$, while the effect of $\mathrm{dmPGE}_{2}$ may be related with relaxation of smooth muscle mediated by EP4 receptors (12). Anyhow, these results suggest a causal relationship between the suppression of intestinal hypermotility and the prevention of bacterial translocation. Intestinal hypermotility may cause the mucosal hypoxia and microvascular injury due to smooth muscle contraction, leading to neutrophil infiltration and release of various cytokines $(22-25)$. Indeed, Anthony et al. (26) showed the importance of the damaging effect of indomethacin on blood flow to regions of the rat small intestine that are sensitive to ischemia. Since inhibition of intestinal motility may prevent the microvascular disturbances due to the intestinal wall contraction, it is possible that thiaton also contributes to maintaining mucosal blood flow in the presence of indomethacin. At present, the mechanism by which indomethacin enhances intestinal motility remains unknown, yet it is assumed that the phenomenon is associated with a PG deficiency and mediated by the cholinergic pathway. It has been reported that indomethacin caused gastric hypermotility through the vagalcholinergic mechanism $(22,27)$. Further studies should certainly be needed to clarify the mechanism by which indomethacin enhances intestinal motility.

It is also known that the mucus layer is a barrier for bacterial invasion into the intestinal mucosa (28). Likewise, enteropooling (intestinal fluid secretion) also contributes to prevent bacterial translocation, by washing out the invaded bacteria. This contention was supported by the fact that both the mucus and fluid secretions were significantly decreased by indomethacin and increased by $\mathrm{dmPGE}_{2}$. Although both thiaton and atropine significantly reverted the decrease in mucus and fluid secretions following indomethacin, these drugs by themselves did not increase but reduced these secretions. It is thus unlikely that the prevention by thiaton and atropine of bacterial translocation is brought about by stimulation of the mucus and/or fluid secretions in the intestine. Morikawa et al. (15) reported that thiaton increased the mucus and bicarbonate secretions in the rat stomach and suggested a role for the mucus/bicarbonate barrier as the mechanism of its gastroprotective action. The reason for these different results on mucus secretion remains unknown, yet it may be due to tissue difference used in the experiments.

On the other hand, it has been shown that indomethacin causes an increase of tumor necrosis factor $\alpha$ (TNF- $\alpha$ ) production in the small intestine, a key cytokine for induction of iNOS in the intestinal lesion model (29). Morikawa et al. (30) recently reported that thiaton protected against indomethacin-induced gastric lesions, by decreasing TNF$\alpha$ production in the mucosa. Thus, it is possible that the protective effect of thiaton observed in this study may be accounted for partly by suppression of TNF- $\alpha$ production 
in the intestinal mucosa.

In conclusion, the present results taken together suggest that thiaton the anti-muscarinic drug protects the small intestinal mucosa against indomethacin-induced damage, as effectively as a $\mathrm{PGE}_{2}$ derivative. The protective effect of thiaton is similarly observed with atropine and is causally related with prevention of enterobacterial translocation, the process probably being accounted for by inhibition of the enhanced intestinal motility caused by indomethacin. Inhibition of the intestinal hypermotility may strengthen a barrier against luminal pathogen, resulting in suppression of bacterial translocation and inhibition of neutrophil recruitment as well as the iNOS up-regulation, and by so doing, prevents the occurrence of small intestinal damage following indomethacin. Thus, it is assumed that thiaton is used as a prophylactic drug against small intestinal damage caused by NSAIDs.

\section{REFERENCES}

1 Robert A and Asano T: Resistance of germ-free rats to indomethacin-induced intestinal inflammation. Prostaglandins 14, 333 - 341 (1977)

2 Fang WF, Broughton A and Jacobson ED: Indomethacin induced intestinal inflammation. Am J Dig Dis 22, 749-760 (1977)

3 Bjarnason I, Zanelli G, Smith T, Prouse P, Williams P, Smethurst P, Declacey G, Gumpel MJ and Levi AJ: Nonsteroidal anit-inflammatory drug-induced intestinal inflammation in humans. Gastroenterology 93, 480 - 489 (1987)

4 Whittle BJR: Temporal relationship between cyclooxygenase inhibition, as measured by prostacyclin biosynthesis, and the gastrointestinal damage induced by indomethacin in rat. Gastroenterology 80, 94 - 98 (1981)

5 Weissenborn U, Maedge S, Buettner D and Sewing KF: Indomethacin-increased gastrointestinal lesions in relation to tissue concentration, food intake and bacterial invasion in the rat. Pharmacology 30, 32 - 39 (1985)

6 Redfern JS, Blair AJ, Lee E and Feldman M: Gastrointestinal ulcer formation in rabbits immunized with prostaglandin $E_{2}$. Gastroenterology 93, 744 - 752 (1987)

7 Yamada T, Deitch E, Specian RD, Perry MA, Sartor RB and Grisham MB: Mechanisms of acute and chronic intestinal inflammation induced by indomethacin. Inflammation 17, 641 662 (1993)

8 Whittle BJR, Laszlo F, Evans AM and Moncada S: Inducible nitric oxide synthase and microvascular injury in the rat jejunum provoked by indomethacin. Br J Pharmacol 116, 2286-2290 (1995)

9 Boughton-Smith N, Evans SM, Laszlo F, Whittle BJR and Moncada S: The induction of nitric oxide synthase and intestinal vascular permeability by endotoxin in the rat. $\mathrm{Br} \mathrm{J}$ Pharmacol 110, 1189 - 1195 (1993)

10 Konaka A, Nishijima M, Tanaka A, Kunikata T, Kato S and Takeuchi K: Nitric oxide, superoxide radicals and mast cells in pathogenesis of indomethacin-induced small intestinal lesions in rats. J Physiol Pharmacol 50, 25 - 38 (1999)
11 Tanaka A, Kunikata T, Konaka A, Kato S and Takeuchi K: Dual action of nitric oxide in pathogenesis of indomethacin-induced small intestinal ulceration in rats. J Physiol Pharmacol 50, 405 - 417 (1999)

12 Kunikata T, Takeeda M, Tanaka A, Kato S and Takeuchi K: E type prostaglandin inhibits indomethacin-induced small intestinal lesions through EP3 and EP4 receptors: A study using rats and knockout mice. Gastroenterology (abstract) 118, A692 (2000)

13 Kubo S, Morikawa K, Matsubara I, Yamazaki M and Kato H: Pharmacological studies on antispasmodics. I. Selectivity to antispasmodic activity of diarylmethylene-5-methyl-transquinolizidinium bromides. Folia Pharmacol Jpn (Nippon Yakurigaku Zasshi) 101, 174-181 (1981) (text in Japanese with English abstract)

14 Kubo S, Morikawa K, Matsubara I, Yamazaki M and Kato H: Pharmacological studies on antispasmodics. III. Antispasmodic activity of 3-(di-2-thienylmethylene)-5-methyl-trans-quinolizidinium bromide (HSR-902) on smooth organs and its organ selectivity. Folia Pharmacol Jpn (Nippon Yakurigaku Zasshi) 77, 87 - 98 (1981) (text in Japanese with English abstract)

15 Morikawa K, Aratani T, Mizutani F, Kato H and Ito Y: Cytoprotective activity of tiquizium bromide (HSR-902) and its mechanism. Folia Pharmacol Jpn (Nippon Yakurigaku Zasshi) 90, 285 - 293 (1987) (text in Japanese with English abstract)

16 Oshita M, Ohashi T, Morikawa K, Kato H, Ito Y and Muramatsu I: Studies on the affinity and selectivity of tiquizium bromide (HSR-902), a novel spasmolytic agent, for muscarinic receptors. Jpn J Pharmacol 44, 222 - 224 (1987)

17 Bradley PP, Priebat DA, Christensen RD and Rothstein G: Measurement of cutaneous inflammation: estimation of neutrophil content with an enzyme marker. J Invest Dermatol 78, $206-$ 209 (1982)

18 Brown JF, Tepperman BL, Hanson PJ, Whittle BJR and Moncada S: Differential distribution of nitric oxide synthase between cell fractions isolated from the rat gastric mucosa. Biochem Biophys Res Commun 184, 680 - 685 (1992)

19 Calignano A, Whittle BJR, Di Rosa M and Moncada S: Involvement of endogenous nitric oxide in the regulation of rat intestinal motility in vivo. Eur J Pharmacol 229, 273 - 276 (1992)

20 Azumi Y, Ohara S, Ishihara K, Okabe H and Hotta K: Correlation of quantitave changes of gastric mucosal glycoproteins with aspirin-induced gastric damage in rats. Gut 21, $533-536$ (1980)

21 Robert A, Nezamis JE, Lancaster C, Hanchar AJ and Klepper MS: Enteropooling assay: A test for diarrhea produced by prostaglandins. Prostaglandins 11, 809 - 828 (1976)

22 Takeuchi K, Ueshima K, Hironaka Y, Fujioka Y, Matsumoto J and Okabe S: Oxygen free radicals and lipid peroxidation in the pathogenesis of gastric mucosal lesions induced by indomethacin in rats. Digestion 49, 175 - 184 (1991)

23 Touloukian RJ, Posch JM and Spencer R: The pathogenesis of ischemic gastroenterocolitis of the neonate: Selective gut mucosal ischemia in asphyxiated neonatal piglets. J Pediatr Surg 7, $194-205$ (1972)

24 Miura S, Suematsu M, Tanaka S, Nagata H, Houzawa S, Suzuki M, Kurose I, Serizawa $\mathrm{H}$ and Tsuchiya M: Microcirculatory disturbance in indomethacin-induced intestinal ulcer. Am J Physiol 261, G213 - G219 (1991)

25 Anthony A, Dhillon AP, Nygard G, Hudson M, Piasecki C, 
Strong P, Travethick MA, Clayton NM, Jordan CC, Pounder RE and Wakefield AJ: Early histological features of small intestinal injury induced by indomethacin. Aliment Pharmacol Ther 7, 29 - 40 (1993)

26 Anthony A, Pounder RE, Dhillon AP and Wakefield AJ: Vascular anatomy defines sites of indomethacin induced jejunal ulceration along the mesenteric margin. Gut 41, 763 - 770 (1997)

27 Takeuchi K, Ueki S and Okabe S: Importance of gastric motility in the pathogenesis of indomethacin-induced gastric lesions in rats. Dig Dis Sci 31, 1114 - 1122 (1986)

28 Whittle BJR: Nitric oxide in gastrointestinal physiology and pathology. In Physiology of the Gastrointestinal Tract, Edited by Johnson LR, 3rd edition, pp 267 - 294, Raven Press, New York (1994)

29 Bertrand V, Guimbaud R, Tulliez M, Mauprivez C, Sogni P, Couturier D, Giroud JP, Chaussade S and Chauvelot-Moachon $\mathrm{L}$ : Increase in tumor necrosis factor- $\alpha$ production linked to the toxicity of indomethacin for the rat small intestine. Br J Pharmacol 124, 1385 - 1394 (1998)

30 Morikawa K, Saito T, Kaburagi H, Yasumori A, Mizutani F, Iwanaga Y, Nagata O, Kato H and Haln K: Role of TNF- $\alpha$ and nitric oxide in the protective effect of tiquizium bromide on indomethacin-induced gastric mucosla injury in rats. Gastroenterology (abstract) 116, A-150 (1999) 